\title{
MĀLPILS DRAUDZES MĀCĪTĀJA OTO ROBERTA FON KLOTA (1808-1876) SPREDIḲIS LATVIEŠU VALODĀ 1851. GADĀ
}

\author{
Dzintra PAEGLE, Pēteris VANAGS \\ Latvijas Universitāte
}

\section{Ievads}

Rakstā pievērsīsimies mācītāja Oto Roberta fon Klota (Otto Robert von Klot) sprediķim (LVVA 1851), kas lasīts latviešu draudzei 1851. gada 11. oktobrī Rīgas apriņķa Mālpils Evaņgeēiski luteriskajā baznīcā vizitācijas laikā. Aplūkosim mācītāja ar roku rakstītā sprediķa saturu un izteiksmi, analizēsim ortogrāfiju, substantīvu, adjektīvu, pronomenu, verbu un prepozīciju lietošanu, apskatīsim dažas sintakses un interpunkcijas īpatnības.

Sprediķa citātos saglabāta orig̣ināla ortogrāfija un interpunkcija, bet pārsvìtrotais $<\mathrm{f}>$ aizstāts ar $<\dot{s}>$.

\section{Roberta fon Klota dzīvesceḷš}

Oto Roberts fon Klots dzimis Nìtaures pastorātā 1808. gada 12. februārī mācītāja, Latviešu literārās jeb draugu biedrības dibinātāja un pirmā prezidenta Gustava Reinholda fon Klota (Gustav Reinhold von Klot, 1780-1855) ğimenē.

Oto Roberts fon Klots viņa dzīves laikā biežāk ir saukts par Robertu fon Klotu, arī par Robertu Oto Klotu, tāpēc šajā rakstā turpmāk lietosim viņa galveno priekšvārdu - Roberts, kā arī iniciāli R.

No 1827. līdz 1830. gadam R. Klots studējis Tērbatā teoloǵiju, studijas turpinājis Berlīnē. Tad bijis mājskolotāis Umurgā. No 1842. līdz 1869. gadam mācītājs Mālpilī. 1869. gada 8. decembrī emeritēts. Līdzās draudzes darbam Mālpilī R. Klots no 1850. līdz 1856. gadam bija skolu revidents Rịgas apriņkīi, no 1856. līdz 1872. gadam - Vidzemes laukskolu virsvaldes padomnieks (Schulrat) (Bearent 1977: 296-297; DBL 389-390; Švābe 1958: 174).

Skolotājs Kārlis Rinkužs (1886-1947), aprakstot Vidzemes skolotāju semināra vadītāja Jāṇa Cimzes (1814-1881) darbību un viņa attieksmes ar šūlrātu R. Klotu, min šādus datus par Klota skolu padomnieka amata laiku no 1856. gada 22. marta līdz 1871. gadam (Rinkužs 1938: 74).

Meklējot plašāku informāciju par R. Klotu tā perioda laikrakstos, atrodamas ziņas, ka 1842. gada 15. janvārī Rīgas Jēkaba baznīcā R. Klots iesvētīts par Mālpils draudzes mācītāju (DI 1842, TLD 1842). 


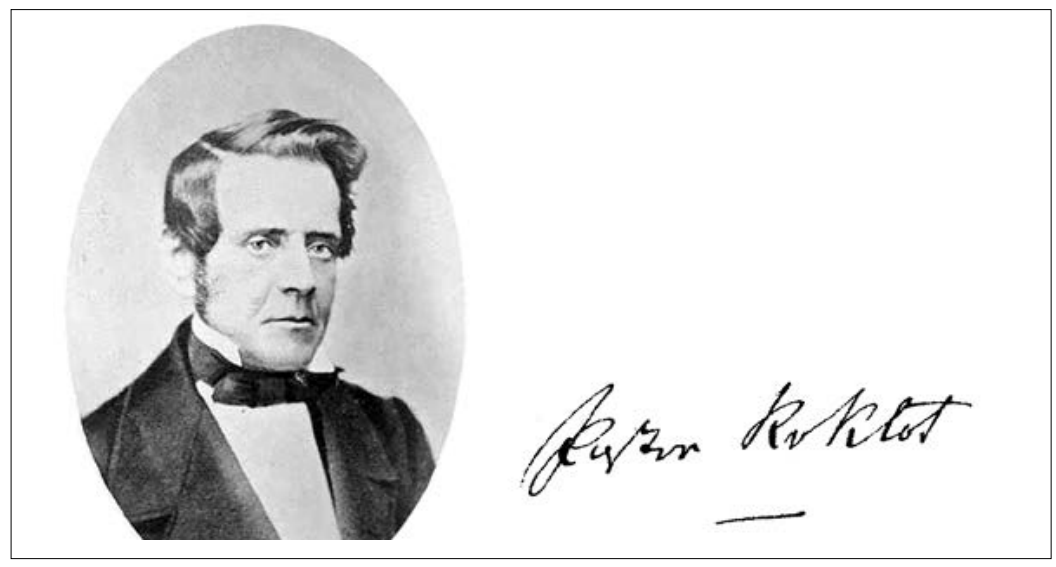

1. att. Roberts fon Klots un vinga paraksts (LVVA, 233. f., 4. apr., 1170. 1., 18. lp)

„Latviešu Avīzēs“ par R. Klota Vidzemes skolu priekšnieka amata uzsākšanas laiku varam uzzināt no E. Dinsberga raksta par Jāņa Cimzes goda dienu. Tur stāstīts, ka 1856. gadā Dr. Ulmanis pārcēlies uz Pēterburgu par augstāko baznīcas tiesas priekšnieku, viņa vietā par Vidzemes skolu priekšnieku iecelts Mālpils mācītājs fon Klots (LA 1864). Bet jau 1857. gadā laikraksts „Das Inland“ ziņo, ka par laukskolu padomnieku viņš kḷuvis 1856. gada martā (DI 1857). Pēc tam, kad 1869. gada 8. decembrī R. Klots ir beidzis darbu Mālpils draudzē, viņš̌ vēl ir palicis amatā par Vidzemes laukskolu priekšnieku (RK 1870). Pēc diviem gadiem, 1871. gada beigās, Klota vietā par Vidzemes skolu priekšnieku ievēlēts mācītājs Teodors Pfeils (Theodor Pfeil, 1828-1913) no Tērbatas (BV 1871).

R. Klota Vidzemes skolu priekšnieka amata laikā ir palielināiies skolu skaits, viņa atskaitē 1856. gadā ir bijušas uzrādītas 103 draudzes skolas un 524 pagastskolas, bet savā pēdējā ziņojumā 1869./70. gadā Klots uzrāda jau 111 draudzes skolas un 811 pagastskolas (RZ 1876).

R. Klots sava amata laikā reizi gadā turpinājis noturēt Turaidā skolotāiju seminārus, kas aizsākušies 1848. gadā. Par to ziņo laikraksti „Mājas Viesis“, „Latviešu Avīzes“, „Baltijas Vēstnesis“. „Mājas Viesis“ apraksta sīkāk, kā noritējis skolmeistaru saiets 1863. gada 26. jūnijā. Tas noticis Turaidas Šveicera mājas lielajā istabā (zālē), bija ieradušies kādi 70 vīri. Semināru sākuši ar dziedāšanu, tad - R. Klota dievvārdi, pēc tam nolasīts pagājušā gada semināra protokols, lai visi zinātu, kas tur runāts. Tad pārsprieduši skolas lietas. Pēc pusdienām izgājuši ārā uz pils torni, tur zem ozoliem daudzbalsīgi 
dziedātas dziesmas Limbažu skolmeistara Šmita kunga vadībā. Un atkal telpās pārrunājuši skolu lietas, strādājuši līdz plkst. 6.30 vakarā, nobeigumā ārā četrbalsīgi dziedājuši tautas dziesmas un „Was ist des Deutschen Vaterland“ un „Unter allen Wipfeln ist Ruh“. Bijuši arī klausītāii. Seminārs turpinājies otrajā dienā (MV 1863). Par R. Klota darbības laiku Vidzemes laukskolās plašāk rakstīịis A. Vičs (1928: 318-433).

Laikrakstos var atrast ziņas, ka pēc amata atstāšanas Mālpilī R. Klots dzīvojis Rīgā un savā dzīves vietā ir izplatīịs dziedātājiem „Dziesmu rotu jaunekļiem un vīriem“ I un II daḷu J. Cimzes redakcijā un iekasējis Atraitņu un bāriņu palīdzības lādes biedru naudu no skolmeistariem. Rakstā ir uzrādīta vecā skolu priekšnieka Klota dzīves vieta: Rīga, Pēterburgas priekšpilsēta (Vorstadt), Lielā Smilšu iela Nr. 31, paša namā (Große Sandstraße No 31, im eigenen Hause) (MV 1872).

Roberts fon Klots miris 1876. gada 15. martā Rīgā, apglabāts, domājams, Jēkaba draudzes kapsētā (RK 1876).

\section{Roberta fon Klota sprediķa saturs un izteiksmes īpatnības}

Mālpils baznīcas vizitācijas laikā 1851. gadā mācītājam R. Klotam ir 43 gadi un 9 gadu pieredze mācītāja darbā. K. Rinkužs (1938: 74) R. Klotu raksturojis šādi: „Klots bija maza auguma, pavājš miesās, tomēr enerğisks un noteikts. Viņš bija konservātīvs un nosvērās uz muižnieku reakcionārā spēka pusi."

Pievērsīsimies dažām sprediḳ̂̄ paustajām domām un izteiksmei.

Pēc ievadvārdiem R. Klots uzrunā draudzi ar visai demokrātisku frāzi - Mīl li ticības biedri! Tomēr uzruna nav oriğināla. Piemēram, aplūkojot „Seniespiedumu kopkatalogu“, redzams, ka ar šādu uzrunu virsrakstā ir apzināti trīs nelieli iespiedumi: divi izdevumi ar Georga Sokolovska paziņojumu „Mīli ticības biedri!“ par žurnālu „Ziņas par Notikumiem iekš Dieva Valstības“ 1832. gada novembrī un decembrī, tie iznākuši Straupes baznīcas kunga muižā, un Krievijas Bībeles biedrības uzaicinājums „Mīli ticības biedri no Latviešu tautas“ 1845. gadā, 2 lpp., bet šā uzaicinājuma neviens eksemplārs nav saglabājies (Seniespiedumi 1999: Nr. 1820, 499; Nr. 1319, 378).

Spredikisis Mālpilī notiek darbdienā, nevis svētdienā, kā parasts, jo tā ir noteikusi baznīcas valdīšana. Mācītājs aizrāda, ka tomēr ir vērts aizkavēt dienas darbu, jo „viena diena iekš taviem pagalmiem labāka nekā tūkstošas citas“:

Mihli tizzibas beedri! Juhs śchodeen śchè śchurp eśśat śaaizinati śchinnî śawâ Deewa-nammâ. - Bet woi tad śchodeen kahda śwehdeena? - Woi 


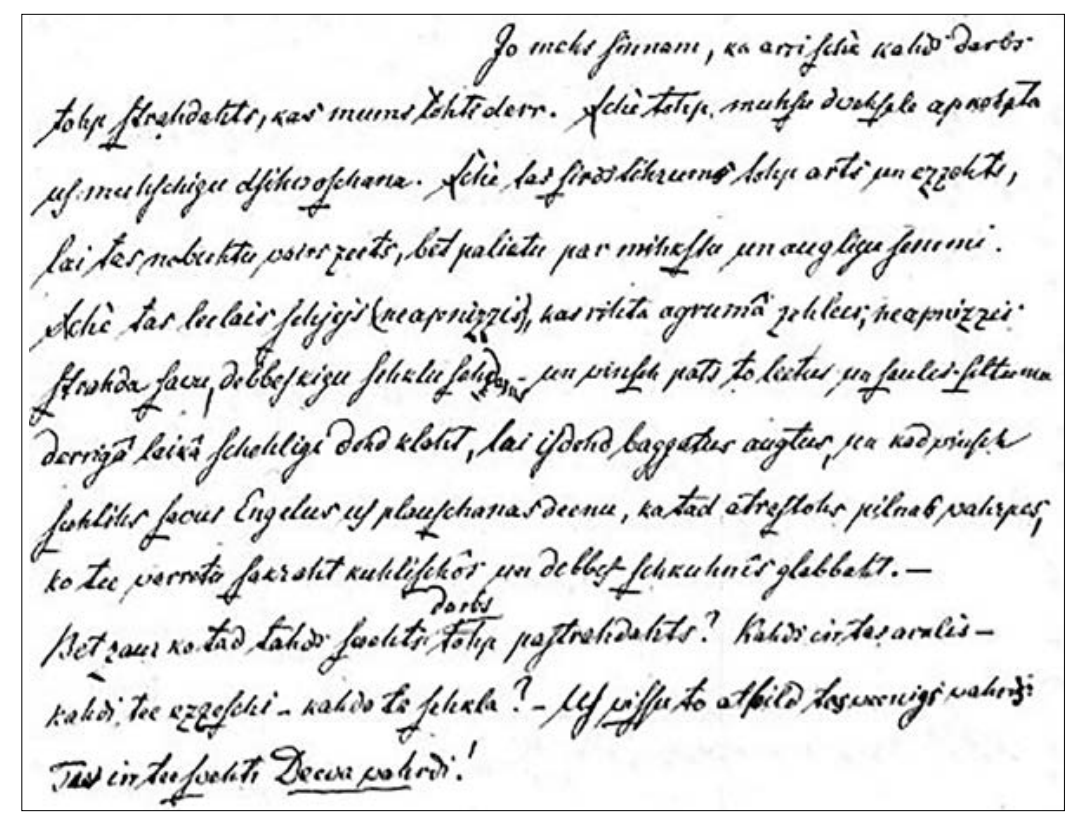

2. att. Roberta fon Klota sprediķa fragments (LVVA 1851: 198. 1p. o. p.)

tad śchee kahdi śwehtki? - Ne, m. t. b., ta gan naw. Bet śchi deena mums nolikta no bafnizas-waldiśchanas preekśchneekeem, pahrraudfiht ścho draudfi un apluhkoht, woi ta Deewa-kalpośchana pee mums noteek kà waijaga, - woi behrni tohp audfehti eekśch ta Kunga Jefus atfihśchanas un pamahziśchanas, - woi laulati draugi mihleśtibâ un śaderribâ dfihwo, - woi ikweens darbojahs eekśch tahm Deewa leetahm, un woi wiśśa śchi draudfe arri dfennahs, tahda draudfe palikt ikdeenas jo wairak, kurrai nebuhtu ne-kahds traipeklis, nedf grumba, nedf zitta kahda waine, bet kas buhtu śwehta un befwainiga, - weena ihśtena Kriftus-bruhte. Bet kahdę śchi leeta naw nolikta uf kahdu śwehdeenu? Kapehz mums nu irr ja-aifkaweh śawu deenas-darbu? - M. t. b., ja ta kahds praśśa, tahds teeścham arri buhtu kuhtris śwehdeenâ śchurp atnahkt. - Bet mehs, kas mahzijuśchees śazziht ar kehningu Dahwidu (26,8): „Kungs, es mihleju to mahjas weetu tawa nā̄a un tawas gohdibas telts-weetu“, mehs arri leezinajam ar to pafchu (Dahw: 84,12): „Weena deena eekśch taweem pagalmeem, ak Kungs, irr labbaka neka tuhkśtośchas zittas. "Jo mehs finnam, ka arri śchè kahds darbs tohp śtrahdahts, kas mums lohti derr. (LVVA 1851: 198. lp.) 
Mācītājs, dvēseles kopšanu tēlodams līdzībās ar zemniekiem tik pazīstamo tīruma aršanu un ecēšanu, saka:

Śchè tohp muhśu dwehśele apkohpta, uf muhfchigu dfihwośchana [tā!]. Śche tas sirdstihrumà tohp arts un ezzehts, lai tas nebuhtu wairs zeets, bet paliktu par mihkśtu un augligu femmi. Śchè tas leelais śehjejs (neapnizzis), kas rihta agrumâ zehlees; neapnizzis śtrahda śawu, debbefkigu [tā!] śehklu śehdams - un wiņśch pats to leetus un śaules-śiltumu derrigâ laikâ fchehligs dohd klaht, lai ifdohd baggatus auglus, un kad wingśch śuhtihs śawus Engelus uf plauśchanas deenu, ka tad atraśtohs pilnas wahrpes, ko tee warretu śakraht kuhliśchôs un debef-śchkuhnîs glabbaht. - Bet zaur ko tad tahds śwehts darbs tohp paftrahdahts? Kahds irr tas arklis - kahdi tee ezześchi - kahda ta śehkla? Uf wiśśu to atbild tas weenigs wahrds: Tee irr tee śwehti Deewa wahrdi! (LVVA 1851: 198. 1p. o. p.)

Mācītājs R. Klots garīgo dzīvi, kalpošanu Dievam tēlo romantiski, gaišās krāsās, tā līdzinās zemes kopšanai, labības sēšanai, audzēšanai un bagātas ražas novākšanai. Dieva vārdus viņ̌̌ salīdzina ar „rihta śauliti pehz nakts-tumśibas“ (LVVA 1851: 199. lp. o. p.), kā arī „Woi ar ścho śaldu peenu ne eśśam ari mehf meerinati“ (LVVA 1851: 201. lp.). Minētajos sprediķa fragmentos iezīmējas romantisms, kas, pēc Ināras Klekeres domām, jau 1816. gadā veidojās Berlīnes Universitātes mācībspēku vidū (Klekere 2011: 91), un Berlīnē ir studējis arī R. Klots.

Tomēr romantisms R. Klota sprediķ̄i izpaužas fragmentāri, tāpat kā 18. gs. beigās dzejas publikācijās, kā to novērojusi I. Klekere (2011: 105).

Mācītājs Klots vēršas pret tiem, kas savu ticību nav pienācīgi kopuši, un salīdzina tos ar nevī̌žìu zemkopi:

Kàdehl tu to femmi licis maitaht no paśaules kahjahm un ratteem? Kàdehl tu to nenokruftijis kà Kriftus apśehtu tihrumu. Kàdehl tu to neaptaiśijis ar śehtahm un ar grahweem un aifdfinnis tohs putnus? (LVVA 1851: 200. 1p.)

Te aprakstīta arī etnogrāfiska zemkopības aina, kas jau 20. gs. sākumā ir zudusi. To piemin valodnieks Juris Plāksis, raizējoties par sena zemkopības veida iznīkšanu un reizē arī vietvārdu zudumu. J. Plāksis (1936: 1) ir novērojis: „Gluži tāpat pazuda nosaukumi senajiem aptaisītajiem un apžogotajiem dārziem jeb laukiem, kad iznīcināja sētas un žogus un laukus pārkārtoja un pārdalīja pēc jauniem lauksaimniecības paraugiem.“

Šajās iepriekš citētajās Klota sprediķa rindās ieskanas aicinājums uz kristīga zemnieka ideālu izturēšanos - pielūgt Dievu un pārmest 
krustu apsētam laukam. Šādu zemnieka dievbijību baznīca audzinājusi gadsimtiem ilgi.

Simboliski putns kā ḷaunums, kas iznīcina dvēselē sētu Dieva sēklu, Klota sprediķ̄ minēts atkārtoti: ,„...] tai dwehśelei, kas teem putneem lạhwuśi, to labbu śehklu apehśt" (LVVA 1851: 200. lp.).

Mācītājs R. Klots spredikịī vismaz divas reizes vēršas pret tiem, kas pāriet svešā ticībā un cer uz pasaules labumiem: „kas pee śchihs draudfes bija peelikti no mafahm deenahm, atśchkihrahs no mums un zittu śwefchu tizzibu kahroja - zerredami paśaules labbumus“"(LVVA 1851: 201. lp. o. p.); „kas zittam Kungam kalpo, neka tam trihf w eenigam Deewam - prohti tai paśaulei - woi śawam wehderam“ (LVVA 1851: 200. lp.).

19. gs. vidū no Mālpils luteriskās draudzes pārgāja pareizticībā 400 cilvēku (KV 1911: 2587), bet no kaimiņu Suntažu draudzes - 1500 cilvēku (KV 1921: 4071), mazliet mazāk nekā puse suntalnieku. Vēsturniece Ieva Pauloviča, aprakstot Mālpils Dievmātes Patvēruma Pareizticīgo draudzes darbību, balstoties uz arhīva dokumentiem, piemin, ka tēvam Aleksejam Lavrovam, „kurš te darbojās no 1847. gada līdz 1858. gadam, [..] bieži nācās aizstāvēt savā draudzē pārgājušos zemniekus, īpaši cīnoties ar Mālpils Luterāņu draudzes mācītāju Oto Robertu fon Klotu, kurš savukārt darīja visu, lai atrunātu zemniekus pāriet pareizticībā, un nosodīja tos, kuri to izdarīịa“ (Pauloviča 2011: 1/11).

R. Klota rīcība vērtējama kā drosmīga, jo cariskajā Krievijā ar represijām vērsās pret tiem, kas bija pret pareizticību. Toreiz, 1846. gadā (spredikịis tiek lasìts 1851. gadā), par šādu rīcību tika slēgts laikraksts „Tas Latviešu Draugs" un tā izdevējs mācītājs Hermanis Treijs (Johannes Hermann Trey) izsūtīts uz Kauņu, represijās cieta arī laikraksta cenzors K. E. Napjerskis (Carl E. Napiersky) (Par to Klekere 2011: 50; Zelče 2009: 155-157).

R. Klots ir neiecietīgs arī pret tiem, kas piekopj elkdievību, teikdams, „kas śawu dwehśeli prettineekam nodewuśchi un kas viņņus mahza pagahnu śkohlâs“. Mācītājs spredikīi min negatīvā nozīmē gan pagānu skolas, gan elkdievību, to pielīdzinādams citiem smagiem kristīga cilvēka grēkiem. Viņš atsaucas uz Svētajiem Rakstiem (1 Kor 6,9): „Nepeewileetees; nedf mauzineeki, nedf elka-deewigi, nedf laulibas pahrkahpeji, nedz mihkftneeki, nedf fagli, nedf negauśchi, nedf dfehreji, nedf lazzekli, nedf laupitaji to Deewa walśtibu neredfehs.“ (LVVA 1851: 201. lp. o. p.) Šajā pārmetumā vārdu savienojums elka dievīgi ir iekḷauts starp daudziem negatīvas nozīmes vārdiem, kurus tagad publiskā runā neatḷaujamies lietot un kuri vairs nepieder pie vispārlietojamās leksikas. Te līdzās elka dievīgiem un laulības pārkāpējiem, minēti mīkstnieki 'g]̣̣ēvuḷi, raudulị' (ME II 643 mîkstnieks, arī 
mîkstulis, ein Weichling, Zärtling), zagli, negauši, dzēēẹi 'dzērāji', laceklıi 'zaimotāji, apmelotāji, mēlneši' (ME II 399 II laceklis, der Verleumder, Lästerer), maucinieki 'staiguli, netikḷi’ (ME II 568 maũcinieks, ein Hurer) un laupītäji.

Mācītājs ar piemēriem rāda, kā Dieva vārds var mierināt lielās bēdās, kad mātes apraud savus mirušos bērnus. Viņš sniedz spilgtu bēdāšanās ainu:

Zik no jums mahtes, kad śchinnî draudfê brehkśchana tappe dfirdeta kà eekśch Ramas (Math. 2, 18), fchehlośchana, raudaśchana un daudf kaukśchanas, un daudf Raëles muhśu śtarpâ apraudaja śawus behrnus un negribbejahs eepreezinajamas, jo tee nebija wairs, — zik tad no jums apbehdinatahm mahtehm irr atśpirguśchees pee teem wahrdeem ta Kunga, kas śakka: „Taws behrninśch naw wifs nomirris, bet tas dufs - un ef win̨nu ufmohdinafchu paftaras-deenâ!“" (LVVA 1851: 201. lp.)

Uz sprediķa beigām, apliecinādams Dieva klātesamību Dievnamā, R. Klots saka: ,... arri pats tas Kungs un Peftitajs irr nośtahjees muhśu widdû apraudfiht ścho śawu draudfi.“ (LVVA 1851: 202. lp.)

Šajos piemēros vērojama mācītāja emocionalitāte un izteikšanās veids. Viņš, izceḷot kādu domu, kārto virknēs sinonīmiskas nozīmes vārdus, panākdams spēcīgāku ekspresivitāti, ko uzskatāmi rāda vairāki sprediķa fragmenti, piemēram, skaļa bēdāšanās apzīmēta: fchehlośchana, raudaśchana un daudf kaukśchanas. Dzīves grūtību tēlojumā minēts bads, likstas, vajāšana, sitieni un cietums: „kas baddu un likśtu - waijaśchanas un śitteenus - un zeetumu paneśśis“ (LVVA 1851: 201. lp.). Turpat tālāk: „Kas muhf śchkirs no Kriftus mihleftibas - woi debbef, jeb bailiba jeb waijaśchana, jeb badds, jeb plikkums, jeb likśta, jeb zobins?“ (LVVA 1851: 201. lp.) Tie, kas nepievēršas Dieva mācībai, raksturoti ar spēcīgu salīdzinājumu: „Mehf gullam un śnaudam kà mirroņu śchkirśtî, un nezillajam nedf kahjas nedf rohkas pee ta ihśtena Deewa-darba prohti muhśu śwehtiśchanas, muhśu śirds irr kà akmiņs un klints - neaugliga femme.“ (LVVA 1851: 199. 1p.) Starp salīdzinājumiem ir savdabīgs: ,.. behdas un śahpes [..], kas mums ufkriht kà kahds śtipri apbruņohts wihrs“ (LVVA 1851: 200. lp. o. p.). Pievēršanu ticīgo dzīvei mācītājs tēlo kā darba procesu, kurā izmantots āmurs un arkls: „Ścho niknu śirdi, kas zeeta kà klints, wiņfch śagraufch ar to ahmuri, kas kalnus śaśitt; ścho neaugligu femini wiņśch ufplehśch ar to aśchu arkli śawas bauślibas .." (LVVA 1851: 199. 1p., 199. 1p. o. p.)

Garīgās dzīves kopšana, cilvēka dvēsele, iekšējā pasaule tiek asociēta ar sirdi. Sirds spredikīī tiek minēta daudzkārt (19 reižu): Śchè tas śirds tihrums tohp arts un ezzehts; muhśu śirds irr kà akmings; śawahs śirds bail ês kleedf; tad eekriht tannî śi rdî kà labb-śataiśihtâfemêê; śawu śirdi irr 
atwehris; Teeścham ta dfihwibas śaulite arri śchè irr atśpihdejuśi daudf śi $r$ î̀ s ; arri pee tawas śi rds zittkahrt tas bauślibas arklis tikke peelikts to ufplehśt; ścho śtundinu eekśch tawas śi rds kriht tà glabbaht; zik reif tu apbehdinahts śazzijis śawấ śirdî̀; ar śirds behdahm; pee śirds leekam; Dewwawahrds irr [..] śohgis to dohmaśchanu un śirds apñemśchanu 'apñemšanos'; ja mehs sawu śi rdi gribbetu dalliht un diwi Kungeem kalpoht; eśśam mannijuśchi peeśawas śirds; bet Deews ufluhko to śirdi; kurirrta śirds, ne kas kalpo wehl dafcheem deewekleem, ko pee śewim turr?

Starp vārda sirds lietojumiem ir arī frazeolog̣ismi, piemēram, jaraud sawâ śirds dibben â. Vārdu savienojums sirds dibenā uzskatāms par novecojušu, tagad - sirds (dvēseles) dzilumos (LFV II 1996: 366). Savdabīgs izteiciens nikna sirds, kas cieta kā klints: Ścho niknu śi r di, kas z e e ta kà klints, sal. cieta sirds 'saka, ja cilvēks ir neiejūtīgs, nežēlīgs, cietsirdīgs' (LFV II 1996: 346). Klota izteicienu varētu uzskatīt par pārveidotu frazeolog̣ismu. Frazeolog̣isms likt pie sirds: lai to pee śirds leekam a r nozīmi 'cenšoties ietekmēt kādu, sirsnīgi ko ieteikt' (LFV II 1996: 354) atbilst mūsdienu valodai.

\section{Roberta fon Klota sprediķa valodas īpatnības}

\subsection{Ortogrāfija}

R. Klota spredik̄ī lietotā latviešu valodas ortogrāfija lielā mērā atbilst 19. gs. pirmās puses rakstībai, tāpēc pilnībā to šeit neaprakstīsim. Viņa jauninājums varētu būt vienkāršā $<\mathrm{v}>$ lietošana dubultā $<\mathrm{w}>$ vietā: voi ikveens darbojahs eekśch tahm Deeva leetahm. Atsevišksos gadījumos ir tomēr rakstīts skaidrs dubultais $<\mathrm{w}>$ : Voi tad śchee kahdi śvehtki? - Ne, m. t. b., ta gan naw; Weena deena eekśch taweem pagalmeem; Tee irr tee śvehti Deeva wahrdi. Reizēm grūti izšksirt, kura no grafēmām lietota. Nav izslēdzama iespēja, ka škịetamais $<\mathrm{v}>$ tomēr ir tikai $<\mathrm{w}>$ rakstības paveids, nevis apzināts citas grafēmas lietojums. Tāpēc rakstā gan škietamais $\langle\mathrm{v}\rangle$, gan $<\mathrm{w}>$ apzīmēti ar tradicionālo $<\mathrm{w}>$.

Atšķirīgs no sava laika paraduma ir grafēmas $<\mathrm{x}>$ lietojums, lai apzīmētu skaņu kopu [ks] vārdā teksts: Par ścheem paścheem runna tee te x te s-wahrdi; No śchi Deewa wahrda śakka muhśu tex tis .

R. Klots rokrakstā neapzīmē skaņu /ḳ/, bet raksta tikai $<\mathrm{k}>$ : Bet mehs, kas mahzijuśchees śazziht ar kehninu Dahwidu; neapnizzis śtrahda śawu, debbefkigu śehklu śehdams; debess śchkuhnîs glabbaht; muhs raht un śchkihśtiht; tur irr śchkelśchanas un śchkirśchanas. Rakstos netiek šksirts arī /g/ no /g̊g/, abus līdzskaņus apzīmējot ar $\langle\mathrm{g}\rangle$ : tohpam pahrwehrstiti eekśch Kriśtus Jefus gihmi; irr śohgis; abbeja puśśê greefigs fohbins. Reizēm netiek uzrādīts /1̦/ un /ņ/ mīkstinājums: deewekleem, fagli, engelus. 
R. Klots apzīmējis mīkstināto /ṛ/ pronomena kuṛš formās: zaur kurrra bruhzehm mehs eśśam dfeedinahti; darrija dfihwus, kurrrus gribbedams, bet citur, piemēram, Apuśt. Pehtera wahrdeem, /ŗ/ mīkstinājuma trūkst.

Nebalsīgais /s/ no balsīgā /z/ škirirts ar burta < $1>$ pārsvītrojumu: wiśśeem, śawâ, śwehdeenu; Jefus, bafnizas, finnam. Tāpat šḳirti /š/ un /ž/: fchehlośchana, śchinnî, eekśch; muhfchigas, dafcheem. Tomēr visai bieži $<1>$ pārsvītrojuma trūkst: muhfu, fehklu, tumfchi.

Prepozīcijas aiz, bez, $u z \mathrm{R}$. Klots raksta ar $\langle\hat{1}\rangle$ : kas irr bef traipekla un bef grumbas; kahdel śchi leeta naw nolikta uf kahdu śwehdeenu; tāpat arī prefiksu atvasinājumos: aifdfinis tohs putnus; befwainiga; lai ifdohd baggatus auglus; kas ufnehmuśchi to dfihwibas graudinu. Tajā paša laika periodā mācītājs F. V. Veirihs prepozīcijas rakstīịis ar $<$ s $>$ (Paegle 2019: 127). R. Klota sprediķa tekstā ar garo $<f>$ vārda galā visai bieži rakstīti arī pronomeni es, mēs: ef, mehf, kur tam noteikti nav fonētiska, bet tikai grafiska nozìme.

Negācija ne- tiek rakstīta ne vien šksirti no verba: ne allojahs, ne buhtu, ne eśmu, ne gribb, ne kalpo, ne taptu, ne-if'śakoht, bet arī koprakstījumā: nebuhs, negribb. Adverbs nekad rakstīts kopā, salīdzinājuma partikula nekā gan kopā: nekà, gan šķirti: ne kà, ne ka, bet saiklis nevien, bet arī kopā: neween - bet arri. Nomeni ar negāciju ne- rakstīti kopā: nenofeedfiba, nezeenigu.

Vārdu debess pamatformā R. Klots parasti raksta ar vienu $<\mathrm{s}>$ kā vārdu bez galotnes: debbes, bet citos locījumos ir lokāmā galotne: debbeśu-tehwa, debbesîis.

\subsection{Fonētika}

Dažos R. Klota rakstītos vārdos lietota fonētiska, nevis morfologíiska rakstība, piemēram, śwehdeena ar /t/ asimilatīvu zudumu. Adjektīvā kūtrs, tāpat kā daḷā vidus izlokšṇu, vārda beigās iesprausts /i/ galotnes -s priekšā: buhtu kuhtris śwehdeenâ śchurp atnahkt.

Pēc sava laika tradīcijas rakstīti vārdi waijaga, waijaśchana - ar $<\mathrm{i}>$ aiz $<$ a $>$ vai $<$ e $>$, ja nākamā zilbe sākas ar $<\mathrm{j}>$ (par to Bergmane, Blinkena 1986: 42). Formā ifeij uzsvērtā pozīcijā pagarināts ej (Pokrotniece 1991: 205). Imperatīva formās sakajt, dfennajtees divskaņa /ai/ otrais komponents rakstīts ar līdzskaņa grafēmu $<\mathbf{j}>$ tāpat kā Jēkaba Langes laikā (Pokrotniece 1991: 203).

R. Klota tekstā lietota forma akmings: Muhśu śirds irr kà akmings un klints - neaugliga femme; kas, ja vien nav rakstības kḷūda, ,rāda nepārveidotu $s$ vārda beigās pēc ņ, piem., cilvēcings“ (Pokrotniece 1991: 206), kā tas vērojams G. Manceḷa, E. Glika, J. Langes u. c. agrāku laiku autoru darbos. 


\subsection{Morfologija}

\subsubsection{Substantīvu formas}

Substantīvu lietošanā ir atsevišķas īpatnības - atš̌kirīga no mūsdienām vārda pamatformas galotne un deklinēšana. Substantīvu o-celmu vietā lietoti iio-celmi: arklis: ar aśchu arkli; āmuris: ar to ahmuri. Dažu substantīvu ā-celmi aizstāti ar $\bar{e}$-celmiem, piemēram, vārpe: pilnas wahrpes; vaine: nedf no śavas grehku waines. Vārds ecēšas lietots vīriešu dzimtē: kahdi tee ezześchi. Tāda forma atrodama arī Stendera, Langes un Bergmaņa vārdnīcās (Zemzare 2011 [1961]: 351). Lietvārdi akmins, zobins, tāpat kā daudzu 18. un 19. gs. autoru darbos, lietoti ar -i- vēsturiskajā piedēklī: aśśaks ne ka abbejâ puśśê greefigs fohbins; paleek par aśśi un greefigu fohbini. K. Mīlenbaha „Latviešu valodas vārdn̄icā" zuobins uzrādīts kā viens no plašāk lietotajiem vārda variantiem tā laika vārdnīcās un Vidzemes izloksnēs (ME IV 756).

Tāpat kā J. Langes „Latviešu Ārstē“ (Pokrotniece 1991: 207), F. V. Veiriha spredikị (Paegle 2019: 129), arī R. Klota spredik̄i ir atrodamas $i$-celma formas ar senu īsu $<\mathrm{i}>$ dsk. datīva galotnē -im: kas preekśch a z zi m irr; pee śawahm kruhtim.

Lietvārds š̌nūnis lietots kā sieviešu dzimtes (?) i-celms dsk. lokatīvā (sal. vācu die Scheune): debess śchkuhnîs glabbaht. Iespējams, ka lietvārds šķirsts lietots kā iìo-celma substantīvs: Mehs gullam un śnaudam kà mirroṇu śkir śt $\hat{\boldsymbol{\imath}}$. Spredikī ir lietota $\bar{a}$-celma g̊enitīva forma no vārda mūžs: ścho muhfchas zellu śtaigajoht. Tas varētu rādīt rakstītāja nepiln̄̄gu latviešu valodas prasmi, kaut, iespējams, sieviešu dzimtes forma fiksēta arī citos avotos (ME II 680).

Starp daudzskaitliniekiem, tādiem kā aśśaras, behdas, mohkas, kildas, śehrgas, ir vārds vienskaitlī - zāle 'viela slimību ārstēšanai': Tee nav wifs ta fahle no Gilead, kas mums ihfteni derr, muhf weśśelus darriht.

\subsubsection{Substantīvu darināšana}

Substantīvu darināšanā visbiežāk izmantota izskaņa -šana, ar to substantīvi darināti no tiešo verbu nenoteiksmes celma. R. Klota spredik̄ī ir konstatēti šādi darinājumi - aicināšana: nedf no śawas a i zi n a śch a nas; apñemšana: irr śahzis to dohmaśchanu un śirds a p ņ em śch a nu; apzēlošana: tas tehws to apfchehlośchanu; atdzemdināšana: tas atdfemdinaśchanas śpehks to śwehtu Deewa-wahrdu; atdzīvināšana: atdfihwinaśchana; atzī̌sana: eekśch ta Kunga Jefus atfihśchanas un pamahziśchanas; bāršana: rahj par [..] bahrśchanu; brēkšana: kad śchinnî draudfê brehkśchana tappe dfirdeta; būšana: śawu nezeenigu buhśch an u noraudadami; ciešana: winnna zeeśchana; domāšana: un irr śohgis to domaśchanu un śirds apnemśchanu; draudēšana: ar śaweem dra udeśch a nas lahśteem; dzī̄ošana: 
uf muhfchigu dfihwośchana [tā!], Jefus dfihwośchana, no tahs Jefus dfihwośchanas; iekārošana: ar [..] meeśas eekahrośchanahm; iepriecināšana: eepreezinaśchanas mums teeścham vaijaga śchinnî behdu-muhfchâ, śpehzigu eepreezinaśchanu; kaukšana: fchehlośchana, raudaśchana un daudf ka u kśch a nas ; miršana: no tahs Jefus dfihwośchanas un mirśch anas; nopūšana: nekad nebuhtu ja-nopuhśchahs ar gruhtahm nopuhśchanahm; nìdēšana: rahj par [..] nihdeśchnu; paciešana: eekśch pazeeśchanas; pamācīšana: pamahziśchana; pazušana: pafuśchana; pāršksiršana: lihdf pahrśchkirśchanai tahs dwehśeles un ta garra; pestī̌sana: par to leelu peśti śch an as darbu śtahśta; pieñemšana: pe eñ em śch a nu eekśch wiśśa labba; plītēšana: rahj par [..] pli h teśch a nu; plaušana: uf plauśc ha nas deenu; raudāšana: raudaśch an a; sadraudzēšana: ta śa draudfeśch a na; staigāšana: winnna śt aiga śch a na; svêtī̄̌nana: muhśu śwehtiśchanas; šķelšana, šķiršana: tur irr śchkelśchanas un śch kirśch an as; taisnošana: un muhśu ta iśno śch a n as dehl; uzbraukšana: ta debbeśî ufbraukśch a na ta Kunga; vajāšana: kas behdu un likśtu vaijaśch a nas un sitteenus [..] paneśśis; valdī̌sana: bafnizas-wal diśch a na; zūdīšana: tur irr nemeeri un fuhdiśchana; žēlošana: fchehlośchana, raudaśchana un daudf kaukśchanas.

Atgriezeniskie substantīvi ar -šanās sprediķa tekstā nav lietoti, to vietā atrodami vairāki atvasinājumi ar -šana: apņemšana: irr śahzis to dohmaśchanu un śirds a p̧̧emśch anu (nevis apñemšanos); nopūšana: nopuhśchahs ar gruhtahm nopuhśchanahm (nevis nopūšanos); šķelšana, šķiršana: tur irr śchkelśchanas un śchkirśchanas (nevis šķ̧elšanās un šķiršanās).

Substantīvu ar -šana lietojums Klota valodā var atškirities no mūsdienu valodas ar gramatisko skaitli: śavu meeśu pee kruśta irr śittuśchi ar tahm kahribahm un meeśas e ekahrohśchanahm (nevis iekārošanu); [..] Jefus wahrdi - Jefus darbi - winnna zeeśch ana (nevis ciešanas) un nahwe pee kruśta.

Substantīvu atvasinājumi ar izskaņu -ība ir lietoti samērā daudz, tie ir vārdi, kas parasti arī mūsdienās: cerība: śawas muhfchigas z er ri ibas ; dievība: rahj par [..] Elka-deewibu; dzī̄ība: tahs muhfchigas dfihwibas; labprātība, laipnība: kas irr [..] labbprahtiba, laipniba; laulība: laulibas pahrkahpeji; līksmība: kas irr [..] li hg s mi ba; mācība: rahj par [..] wiltigahm mahzibahm; mīlestība: ta mihleftiba Dewa ta Tehwa; patiesība: eekśch tawas pateeśibas; saderība: woi laulati draugi [..] śaderribâ dfihwo; skaudība: rahj par [..] śkaudibu; slimība: tur irr śli īibas un śehrgas; ticība: Mihli tizzibas beedri; viltība: wilt iba naw atraśta; žēlastība: ta fchehlaftiba muhfu Kunga. 
Starp darinājumiem ar -ība ir tādi vārdi, kurus mūsdienās lieto reti vai nelieto nemaz: bauslība 'baušli, to mācība': tas ba ús li b a s arklis; bezvainība 'nevainība': zaur śawu befwai ni bu; kārība 'kārdinājums': tai paśaulei un winnas kahribahm; nenoziedzïba 'nevainība': zaur śawu n en ofe edfi bu . Dalıa atvasinājumu ir tādi, kam tagad ir cita nozīme, piemēram, burvība nenozīmē 'burvestība; buršanās', kā Klots to ir lietojis, bet gan 'neparasts skaistums': rahj par Elka-deewibu, bu rwibu. Vārdu tumsība tagad lieto ar nozīmi 'neizglītotība', nevis 'tumsa' kā sprediks̄i, kaut gan arī te ir nozīmes pārnesums plašākā kontekstā: śpihd kà rihta śaulite pehz nakts tu m śi ba s .

Daḷa tā laika darinājumu ar -ība mūsdienās vairs netiek lietoti, to vietā izmanto īsāku vārdu, piemēram, duśmiba 'dusmas', eenaidiba 'ienaids', bailiba 'bailes'. Jāpiebilst, ka Klota spredik̦ī atrodama gan bailība, gan bailes: Kas muhs śchkirs [..] jeb ba ilib a jeb waijaśchana; kurrôs gan no bail eh m bija ja-ifnihkft.

Līdz̄̄gi lietoti atvasinājumi ar izskaņu -ums. Te ir substantīvi, kas parasti mūsdienās: agrums: kas rihta agrumâ zehlees; cietums: kas [..] ze et u mu paneśśis; gaišums: lai tohs darram par [..] weenu g a iś ch u mu uf wiśśeem muhśu zelleem; labums: zerredami paśaules la bbumus; siltums: winśch [..] śaulesśil t u mu derrigâ laikâfchehligi dohd; tīrums: tas śirds ti hru ms ; trūkums: tur irr tru hku ms un bads; bet vārds plikums lietots ar nozīmi 'nabadzība' (ME III 345, die Armut): Kas muhf śchkirs no Kriftus mihleśtibas - voi debbef, jeb bailiba jeb vaijaśchana, jeb badds, jeb plikkums, jeb likśta, jeb fohbins? Mūsdienās neierasts ir vārds nopelnums 'nopelns, alga', kas spredikī lietots vairākas reizes: un wingna dahrga no p el numa pee kruśta; tas grehku nopelnums irr ta nahwe; ar Kriftus dahrgu un śwehtu no pel n u mu . Vārds nopelnums, spriežot pēc vārdlietojuma periodikā, izplatīts 19. gs. un retu reizi 20. gs. sākumā.

Vairāki darītāju apzīmējumi, kas darināti no verbiem, atvasināti ar piedēklịiem -ējs, -tājs - dzēerejs 'dzērājs': nedf df eh reji [..] to Deewa walftibu neredfehs; pārkāpējs: nedf laulibas pahrkah peji [..] to Deewa walftibu neredfehs; sèjējs: Śchè tas leelais ś e h jejs [...] neapnizzis śtrahda; laupītājs: nedf la u pitaji [..] to Deewa walftibu neredfehs.

Personu apzīmējumi darināti arī ar piedēkli -nieks - grēcinieks: jo mehs grehzineeki wiśśi lihdf; ienaidnieks: kas irr Kriftus e en ai dneeki; maucinieks 'staigulis, netiklis', mīkstnieks 'g̣̦ēvulis, raudulis': nedf ma uzin e eki, [..] nedf mihkftneeki [..] to Deewa walftibu neredfehs; pretinieks: woi kas śawu dwehśeli prettin eek a m nodewuśchi.

Visai bieži Klota sprediķī atrodami arī atvasinājumi ar -(e)kl-. Tie ir gan mūsdienu valodā tādā pašā nozīmē lietoti lietvārdi - loceklis: lihdf pahrśchkirśchanai tahs dwehśeles un ta garra, to lo h zeklu un to śmadfenu; māceklis: tee mahzekli un Apuśtuli; gan vārdi ar nedaudz atškisīiou nozīmi - dieveklis 
'elks': Kur irr ta śirds, ne kas kalpo wehl dafcheem d e ew ekl e em, ko pee śewim turr?; spīdeklis 'apgaismojums': lai tohs darram par muhśu kahju śpi h d ekli. Divi lietvārdi mūsdienu valodā vispār netiek lietoti - laceklis 'zaimotājs; apmelotājs': nedf la z zekli [..] to Deewa walftibu neredfehs; traipeklis 'traips': kurrai nebuhtu ne kahds tra i p ek li s, nedf grumba, nedf zitta kahda waine; kas bef traipekla un bef grumbas.

Savā spredik̄̄i Klots labprāt lietojis arī deminutīvus, kas darināti atbilstoši tradicionālajam rakstu valodas modelim ar piedēkḷiem -ing- un - $\bar{l} t-$, piemēram, kà mahte darra ar śawu nemeerigu beh rningu; taws behrninfch naw wifs nomirris; eekśch wingna śchehlaśtibas ga ifm iñas; śchi irr ta ga ifm iña kas winnnam śpihd; no śchi śinnepa graudinga; kas ufnehmufchi to dfihwibas g rau d in u; kas ścho śt un di inu eekśch tawas śirds kriht; ko tee warretu śakraht kuh liśchôs; śpihd kà rihta śa u lite pehz nakts; ta dfihwibas śa ulite arri śchè irr atśpihdejuśi.

\subsubsection{Adjektīvi}

Adjektīvu sprediḳ̄i ir samērā maz, tie ir primāri vārdi, kā akls, ass, ašs, bagāts, ciets, dārgs, dzīus, kūtris, labs, liels, mīksts, mīlšs, nikns, pilns, salds, stiprs, svešs, svèts, tukšs, tumšs, vecs, vesels, piemēram, lai tas nebuhtu wairs ze et bet paliktu par mi hkśt u un augligu femmi; Tee irr tee śwe h ti Deewa wahrdi; woi naw welti śluddinati un neatgreefiśees $t u k f c h i$; kā arī atvasināti vārdi, galvenokārt ar izskaņu -īgs: auglīgs, bezvainīgs, cienīgs, derīgs, dusmīgs, griezìgs, iznīcīgs, kristīgs, mierīgs, mūž̀̆gs, neauglīgs, necienīgs, neiznīcīgs, nemierīgs, pilnīgs, spēcīgs, vienīgs, viltīgs, žēlìgs, piemēram, paliktu par mihkśtu un a ugligu femmi; no śawas mu hfchigas aizinaśchanas; kà mahte darra ar śawu ne me e rig u behrniņu. Starp atvasinājumiem ar -īgs ir atvasinājums brīn-išķigs: Ak teeścham un pateeśi b ri h n iśch kig s irr tas atdfemdinaśchanas śpehks; saliktenis trīsvienīgs: kas zittam kungam kalpo, ne kà tam trihfweeniga m Deewam. Ir daži atvasinājumi ar -ens - istens: weena i $h$ śte n a Kriftus-bruhte; pee ta i h śt en a Deewa-darba; ar -āds: visāds, un -ējs: abējs.

Adjektīvam ass ir paralēli varianti - ass un ašs: śwehti tavus aśśus wahrdus pee mums; ścho neaugligu femi winfch ufplehśch ar to a śch u arkli śawas bauślibas. Vārds ašs ar nozīmi 'ass' reǵistrēts arī ME I 147.

Vairākas reizes tekstā lietotas adjektīvu pārākās pakāpes formas: $a$ ś $s$ aks ne ka kahds abbejâ pusśsê greefigs fohbins; weena deena eekśch taweem pagalmeem [..] irr la bbak a ne ka tuhkśtośchas zittas.

Atsevišksos gadījumos spredik̄i lietots adjektīvs ar noteikto galotni - vīriešu dzimtes vsk. nom./vok.: Bet tu ak śweh ta is Deews śwehti muhf; Tee irr tee wahrdi, ko tas wiśśuśpehzigais śwehtais un fchehligais Deews [..] 
uf teem tehweem irr runnajis; irr ufaudfis tas le el a is kohks tahs kriftigas draudfes; dsk. nom./vok.: ak, mi hle e, bet citos locijumos - nenoteiktā galotne: ścho nea ugligu femi; tahs kriftigas draudfes. Nenoteiktā galotne reizēm lietota arī vokatīvā: Mihḷ i tizzibas beedri!

\subsubsection{Pronomeni}

Personu pronomeni R. Klota sprediķ̄i ir tie paši kā mūsdienu valodā. $E s, t u$, kā arī atgriezeniskais sevis ar prepozīcijām lietoti vecā instrumentāla formā: Un kad juhs ar man [n] i m ar śirds behdahm redfehjufchi śchinnîs gaddôs; arri tu eśśi kohpts un pe e tewi m irr śtrahdahts ka waijaga; Kur irr ta śirds, ne kas kalpo wehl dafcheem deewekleem, ko pee ś ew i m turr? Savukārt akuzatīvā lietotas bezgalotnes formas tev, sev: Eij prohm, ef tew nekad ne-efmu pafinnis; Tad lai pahrraudfamees s ew paśchus kahdi mehs eśśam. 3. pers. pronomeni viņš, vinga lietoti arī norādāmā pronomena tas, tā nozīmē: Arri tu eśśi kohpta no ścheem Deewa-wahrdeem, -- woi tu eśśi mannijuśi wi ñņu atdfemdinaśchanas śpehku?; tad tu gan redfeśi kahds dfihwibas kohks ufaugs ka tu no wi ņņ a lappahm warreśi dfihwoht muhfchigi.

Norādāmie pronomeni ir līdzīgi mūsdienu valodai, lokatīvā lietotas tikai formas šinī, tanī, šinīs: Juhs śchodeen śchè śchurp eśśat śaaizinati śch in n î śawâ Deewa-nammâ; tad eekriht ta n nî śirdî kà labb-śataiśihtâ fem̄ê; Bet śc hi in nîs leetâs mehs ufwahram daudf zaur to, kas muhs ir mihlejis.

Pronomens tas bieži lietots arī vācu valodas noteiktā artikula funkcijā: Ta fchehlastiba muhśu Kunga Jefus Kriśtus, ta mihlestiba Deewa ta Tehwa un ta śadraudfeśchana ta Śwehta Garra lai irr ar mums wiśśeem; un tas grehku nopelnums irr ta nahwe.

\subsubsection{Verbi}

Verbu lietojums R. Klota sprediķī atbilst 18. un 19. gs. rakstu valodai. İstenības izteiksmē lietota galvenokārt verba vienkāršā un saliktā tagadne, vienkāršā un saliktā nākotne.

Tagadnes dsk. 1. pers. verbi parasti ir ar galotni -am: eśśam, gullam, nefinnam, śauzam, śnaudam, ufwahram 'uzvaram', waidam.

Tagadnes 3. pers. refleksīvo verbu formas, neatkarīgi no verba celma, lietotas ar garo patskani /ā/ galotnē: darbojahs, dfenahs, ifplattahs, neturahs, raugahs. Šāda īpatnība „raksturīga latviešu rakstu valodai, sākot ar visvecākajiem 16. gs. tekstiem, sarunvalodā un izloksnēs tā sastopama līdz pat mūsdienām“" (Pokrotniece 1991: 209-210).

Pāris gadījumos verba pagātnes galotne ir -e: neśśe muhśu śehrgas; te pagātnes 3. pers. nese varētu būt dialekta forma, sens $\bar{e}$-celms (Endzelīns 
1951: 679), bet ciešamās kārtas palīgverba tikt pagātnes forma tike ir jaunināta, iespējams, viduslejasvācu valodas ietekmē (Blese 1929: 29): tas bauślibas arklis tik ke peelikts to ufplehśt. Šādas verbu pagātnes formas ar $<\mathrm{e}>$ galotnē līdz 19. gadsimta vidum bija izplatītas daudz biežāk (sal. Vanags 2015: 53). Sprediḳī ir daži verbi, kuru tagadnes celma forma atšķiras no mūsdienās lietotās:

atrasties - atronas: ka wiśśur arri wehl at ro hn a h s tahdu, kas irr Kriśtus eenaidneeki, lietots kā tagadnes no-celma verbs (ELVG: 750);

iepriecināt - tagadnes 3. pers. ir iepriecinā kā dạ̦ā vidus izlokšņu (Rudzīte 1964: 134): kas muhs e epreezina h wiśśâs muhśu behdâs;

snaust - vidus izlokšņu forma tagadnes dsk. 3. pers. ir snaudam (Rudzīte 1964: 134): Mehs gullam un śnaudam .

Atšķirīga celma forma varētu būt arī tagadnes 3. pers. forma ar galotni -a: apdrauda: Ka tee Deewa-wahrdi muhs ap d ra u da weenumehr śazzidami.

Vēlējuma izteiksmē visās atrodamās vsk. un dsk. personās lietots formants -tu resp. -tos: un ja tu śchodeen wehl ta gribbetu darriht; lai tas nebuhtu wairs zeets, bet paliktu par mihkśtu un augligu femmi; ka tad a trafto hs pilnas wahrpes, ko tee war retu śakraht kuhliśchôs; lai zilweku dwehśeles at dfi i w wo to hs un peedfim tu no jauna; ja tahds śchodeen śchurp buhtu atnahzis, tam ef gribbu ufśaukt; ja tas Kungs nebuhtu bijis ar śaweem wahrdeem.

Atstāstījuma izteiksme lietota gan vienk. tagadnē, gan nākotnē: No śchi Deewa wahrda śakka muhśu textis, ka tas eśśoht dfihws; Deewa wahrdi, kas śakka, ka ta notikśchoht uf preekśchu.

Vajadzības izteikšanai sprediḳi visai bieži ir lietota konstrukcija ar dat. + jā-: Kapehz mums nu irr ja-a ifk a weh śawu deenas-darbu?; nahk tas laiks, kad ikkatram jaśa kka, kà Iabs śazzija uf Zowaru; woi no ta mums śchodeen naw ja-le ezina preekśch Deewa un zilwekeem; mums arween no jauna pee winnna zellleem jakriht un ja-fakka; tev bija ja-śakka. Vairrākkārt vajadzība ir izteikta ar konstrukciju büt + nenoteiksme - gan citātos no Bībeles: ka tam ne buhf tukścham pee winnna atgreeśtees, bet darriht, ka wingnam patihk, - un ka tam buhf ifdohtees, uf ko tas tohp fuhtihts; wiśśeem buhf eeeet Deewa walftibâ zaur daudf zeefchanam; gan autora paša tekstā: jo jums buhf pilnigeem buht. Reizēm vajadzība ir izteikta leksiski ar verbu vajadzêt: woi ta Deewa-kalpośchana pee mums noteek kà wai jaga; arri tu eśśi kohpts un pee tewim irr śtrahdahts ka wa ijag a; eepreezinaśchanas mums teeścham wai jaga śchinnî behdu-muhfchâ; tad mums nepeetruhks, kas mums waijaga.

Pavēles izteiksmes vsk. 2. pers. forma sakrīt ar īstenības izteiksmi: Bet tu ak śwehtais Deews, śwehti muhf eekśch tawas pateeśibas. Dsk. 2. pers. 
lietotas formas ar galotni -ait, t. i., -ajt vai -aijt (par to Endzelīns 1951: 888): dfennajtees pehz śwehtiśchanas; Śakaijt jelle - t. b.,- woi tad eśśam mehf [..] śwehta garra pilni. Dsk. 1. pers. pamudinājums izteikts ar nākotnes formu: A pzer reśi im tad pehz ścheem wahrdeem, ko nupatt klauśfijufchees [..] un jautaśimees; śo hliśi m winnam śchodeen atkal; un lu hgśi mees beidfoht; vai arī ar tagadnes formu un partikulu lai: Tad la i pahr raudfa mees sew paśchus kahdi mehs eśśam, un lai praśśamees, woi mehs eśśam tahda draudfe; Tadehl lai wiśśi pateiza m śawam Deewam. Reizēm imperatīva formu pastiprina partikula jele: ne dohma jelle aifbildinatees. Imperatīva dsk. 1. pers. forma lai pahr raudfamees veidota no verba nenoteiksmes saknes - pārraudzìties.

Verba divdabju formas sprediḳ̂̄ ir lietotas visai bieži, trūkst tikai darāmās kārtas tagadnes divdabju ar izskaņām -ošs, -oša un nelokāmo divdabju ar -am, $-\bar{a} m$.

Darāmās kārtas pagātnes divdabji ar -is, -usi, -ies, -usies veido verbu saliktos laikus, reizēm izlaižot palīgverba tagadnes formu ir: Arrī mehs eśś a m gruhtus gaddus peedfihwojuśchi; Es to Kungu eśmu redfejis un manna dwehsele irr meerig tap puśi; zik reif tu apbehdinahts śazzijis śawâ śirdî: Kur es maifi ñemśchu; bet mehs, kas mahzijuśchees śazziht ar kehninu Dahwidu. Šis divdabis lietots arī kā sekundārais predikatīvais komponents: śchè tas leelais śehjejs, kas rihta agrumâ zehlees, ne ap nizzis śtrahda; un kā apzīmētājs: Tas Gars ta debbeśîs ufbraukuśch a Kunga.

Kā vēl 19. gs. pirmajā pusē parasts (Rosenberger 1830: 60-61), šo divdabju vīr. dz. dsk. forma no atgriezeniskajiem verbiem lietota arī sieviešu dzimtes nozīmē: [..] bet arri wiśśu to le et u dehl, kas zaur grehkeem zehluśchees; zik tad no jums apbehdinatahm mahtehm irr atfpirguśchees pee teem wahrdeem ta Kunga.

Ciešamās kārtas pagātnes divdabji ar -ts, -ta lietoti ciešamās kārtas laika formu veidošanā: vienkāršie laiki parasti ar tapt: woi behrni to hp audfehti eekśch ta Kunga Jefus atfihśchanas un pamahziśchanas; śche tas sirds tihrums to hp arts un ezzehts; tad juhs fihdiśeet un tapfeet klehpî $n$ eś $t$; ; vienu reizi arī ar tikt: Arri pee tawas śirds zittkahrt tas bauślibas arklis tikke peelikts to ufplehśt; saliktie laiki - ar būt, kas var būt arī izlaists: Juhs śchodeen śchè eśśat fa aizinati; bet kadehl śchi leeta naw nolikta uf kahdu śwehdeenu?; zaur kurro bruhzehm mehf eśśam dfeedinati; bet śchi deena mums nolikta no bafnizas-waldiśchanas preekśchneekeem. Šis divdabis lietots arī kā sekundāri predikatīvais komponents: woi mehf ap k a u n et $i$ no Jefu leelas mihleftibas, winnnam ikdeenas pee kahjahm krihtam; un kā apzīmētājs: Kas mums ufkriht kà kahds śtipri a pbrungohts wihrs; 
zik tad no jums apbehdinatahm mahtehm irr atfpirguśchees pee teem wahrdeem ta Kunga.

Ciešamās kārtas tagadnes divdabis ar -ams konstatēts tikai vienu reizi: daudf Raëles muhśu śtarpâ apraudaja śawus behrnus - un negribbejahs eepreezinajamas.

Divdabis ar -dams lietots kā mūsdienās saistījumā ar verbu, bet ne par substantīva apzīmētāju: ta wingśch li h gśmodamees dfeed; arī veidojot divdabja teicienu: ja winfch, at fi h da m s fawu grehku-buhfchanu [..] śawâs śirds bailês kleeds ar Pahwilu; zittu śweśchu tizzibu kahroja-zer reda mi paśaules labumus; Woi eśśam mehs atśazzijuśchi pa wiśśam tai paśśaulei un wiņñas kahribahm, ka Jefus Kriśtus darrija - eekśch win̨nga pehdahm mihdami?

Divdabis ar -ot arī lietots dažas reizes: Kur irr kam ne-muhfcham aśśaras ne buhtu jabirrina ścho muhfchas zellu ś ta iga jo ht ; śohliśim wingñam śchodeen atkal [..] un luhgśimees beidfoht ta; divreiz tekstā atrodams arī tā laika rakstu valodā sastopamais, taču nevēlamais (Endzelīns, Mīlenbahs 1907: 148) neizsakot 'neizsakāmi': par weenu neifśa ko ht leelu un śpehzigu eepreezinaśchanu; Ka winfch zaur śawu befwainibu un nenofeedfibu, un ne ifśa ko ht leelu mihleśtibu mums [..] muhśu waines ufrahda.

Analizētajā R. Klota sprediḳī atrodami arī atsevišḳi verbi, kas mūsdienās vairs netiek lietoti, mainījušās nozīmes, atškiras saknes vai piedēkḷ̆a forma: aloties 'kḷūīities' (ME I 69): Kas neallojahs dafchkahrt wehl; tagad plašāk pazīstams no R. Blaumaņa daiḷrades;

audzēt 'audzināt' lietots tāpat kā latviešu folklorā arī attiecībā uz cilvēkiem, ne tikai uz augiem vai dzīvniekiem (ME I 215, 216): woi behrni tohp a udfe hti eekśch ta Kunga Jefus atfihśchanas un pamahziśchanas;

birināt 'birdināt' reg̣istrēts Zasā un Langes vārdnīcā (ME I 298): kam ne-muhfcham aśśaras ne buhtu ja-birrina;

darīt 'radīt': zaur to wahrdu śawas muttes debbes un femmi ir darrijis, bet turpat arī darīt veselus: muhs weśśelus darriht; darìt dzīous kā mūsdienās: tas wahrds, kas dfihwus darra; vai arī ar nozīmi 'veikt, rīkoties': bet da rrriht, kas wiņnam patihk;

dzisināt 'dzesēt, atvieglot': Tas naw wiśs tas wihns un elje, kas muhśu śahpes dfiśśina (ME II 566, dzisināt 'atvēsināt');

dzīties 'tiekties': woi wiśśa śchi draudfe arri dfe n n a h s, tahda draudfe palikt ikdeenas jo wairak; kà tee ufśkubbina dfi h te e s pehz teem Garra augleem; izdot 'dot': la i ifdohd baggatus auglus (ME I 730, izduôt 2) izvirzīties no iekšpuses, laut lai aug), mūsdienās šajā nozīmē parasti saka: dod - lai dod bagātus auģıs; 
palikt 'kḷūt': pa likt u par mihkśtu un augligu femmi. Tomēr arī mūsdienu valodā verbu palikt lieto saitiņas kḷ̂ut nozīmē, kaut arī literārās valodas norma to neiesaka;

pārvērtīt 'pārvērst' (ME III 187 - no Glika Bībeles tulkojuma): un augam ikdeenas un pilnīgi tohpam un tohpam pahrwehrtiti eekśch Kriśtus Jefus gihmi;

uzvārēt 'uzvarēt' (ME IV 397): Bet śchinnîs leetâs mehs ufwa h ra m daudf zaur to, kas muhs ir mihlejis.

Refleksīvo verbu lietošanā Klota spredik̦ī vairākos gadījumos ir vērojamas atškirīības no mūsdienām:

jautāties 'jautāt': Jau taśi mees, woi tee arri pee śchihs draudfes tahdu śpehku irr parahdijuśchi;

pazusties 'pazust': negribb, ka mums buhs pafuśtees;

prasīties 'prasīt, jautāt': un lai praśśa mees, woi mehs eśśam tahda draudfe.

\subsubsection{Prepozīcijas}

Prepozīcijas un to pārvaldījums R. Klota sprediḳ̂̄ lielākoties atbilst mūsdienu latviešu valodas lietojumam. Atšksirības redzamas vairāku prepozīciju lietojumā: caur, iekš, no, priekš, uz, kas daḷēji var būt radušās vācu valodas ietekmē.

caur - norāda darbības veicinātāiju kā vācu valodā: Bet zaur ko tad tahds śwehts darbs tohp paftrahdahts?; Bet no śchihs grehku-nahwes tas Kungs muhf gribb ufmohdinaht zaur to balśi śawas muttes; Bet śchinnîs leetâs mehf ufwahram daudf zaur to, kas muhf ir mihlejis.

iekš - lietots lokatīva vietā: woi behrni tohp audfehti e ekśch ta Kunga Jefus atfihśchanas un pamahziśchanas; woi ikweens darbojahs eekśch tahm Deewa le e ta h m; śchośtundinu e ekśch tawas śirds kriht tà glabbaht.

no - var norādīt uz darbības veicēju ciešamās kārtas konstrukcijās: śchi deena mums nolikta no bafnizas-waldiśchanas preekśchneekeem; tee irr tee wahrdi, ko tee śwehti wihri irr ufrakśtijuśchi, dfihti no Śwehta Ga r ra; saistīta ar verbiem sacīt, zināt, liecināt pēc vācu valodas modeḷa (sagen, wissen, zeugen von): No śchi Deewa wahrda śakka muhśu textis; mehs nefinnam no Deewa, kahds winfch irr; woi no ta mums śchodeen naw ja-le ez in a preekśch Deewa un zilwekeem.

priekš - lietots adresāta nozīmē: Kur ef maifi ñemfchu preekśch tik da udfe e m; adverbiāli - lietvārda lokatīva priekšā nozīmē: woi no ta mums śchodeen naw ja-leezina preekśch Deewa un zilwekeem. 
$u z$ - var norādīt darbības nolūku, objektu, laiku: Śchè tohp muhśu dwehśele apkohpta, uf muhfchigu dfihwośchana [tā!]; Un uf ko winfch tohp śuhtihts, ja ne uf to, lai zilweku dwehśeles atdfihwotohs; tas wiśśuśpehzigais śwehtais un fchehligais Deews [..] uf teem tehweem irr runnajis; bet kadehl śchi leeta naw nolikta uf kahdu śwehdeenu?

\subsection{Sintakses īpatnības}

Tāpat kā daudzos 19. gs. sākuma un vidus tekstos, arī R. Klota sprediḳ̂̄ vācu valodas iespaidā nesaskaņotā apzīmētāja grupa bieži novietota aiz apzīmējamā vārda (par to Pokrotniece 1991: 217; Vanags 2013: 182): Ta fchehlastiba muhśu Kunga Jefus Kriśtus, ta mihlestiba Deewa ta Tehwa un ta śadraudfeśchana ta Śwehta Garra lai irr ar mums wiśśeem; Kahds tas śpehks to De ewa-wardu?; Ar ścho śaldu peenu śawas muhfchigas zerribas winfch muhfapkluśśina.

R. Klota sprediḳi nolieguma teikumos atšksirīgi no daudziem citiem sava laika avotiem, piemēram, F. V. Veiriha sprediķa (Paegle 2019: 140), konsekventi lietots divkāršais noliegums; kurrai nebuhtu ne-kahds traipeklis; un kam nekad nebu htu ja-nopuhśchahs ar gruhtahm nopuhśchanahm; tad mums nekad nepeetruhks, kas mums waijaga.

Dažas savdabības un svārstības redzamas locījumu lietojumā. Arhaiska, ja vien autentiska, ir ǵenitīva forma subjekta funkcijā, izsakot nenoteiktu daudzumu (Endzelīns 1951: 556): ka wiśśur arri wehl atrohnahs ta hdu, kas irr Kriśtus eenaidneeki.

Lìdzās verbam nebūt nolieguma teikumos parasti lietots nevis ǵenitīvs, bet nominatīvs: kurrai nebuhtu ne-kahds traip eklis; daudf Raëles muhśu śtarpâ apraudaja śawus behrnus - un negribbejahs eepreezinajamas, jo tee nebija wairs; kam naw nekahda waine.

Nominatīvs ğenitīva vietā atrodams arī līdzās verbam trūkt: Jo te e a u gḷ $i$ tam kohkam tru h kft un winnnu ja-nozehrt. Ar formu vajaga var būt saistīts gan genitīvs, gan nominatīvs: e epre ezin aśch a nas mums teeścham waijaga śchinnî behdu-muhfchâ; tad mums nepeetruhks, kas mums waijaga.

Savukārt aiz verba vajadzības izteiksmē tiek lietots substantīvs akuzatīvā: Jo tee augli tam kohkam truhkft un wiņņu ja-nozehrt; Kapehz mums nu irr ja-aifkaweh śawu deenas-darbu?

Ar apstākḷa vārdu daudz biedrojas ne tikai g̊enitīvs, bet arī citi locījumi: ta dfihwibas śaulite arri śchè irr atśpihdejuśi daudf śirdîs; uf daudf dweh ś ele h m gan drihkśt śazziht ar preeku; wiśśeem buhf eeeet Deewa walftibâ zaur daudf zeefchanam. 


\subsection{Interpunkcija}

Pieturzīmju lietošanā sprediķa tekstā nav sistēmas, vietumis komati ir likti iederīgi, bet daudzviet to trūkst:

Un [,] ja tu śchodeen wehl ta gribbetu darriht, un to paśchu graudinu, kas ścho śtundinu eekśch tawas śirds kriht [,] tà glabaht: tad tu gan redfehśi [,] kahds dfihwibas kohks no ta ufaugs [,] ka tu no winnna lapahm warreśi dfihwoht muhfchigi. (LVVA 1851: 200. 1p.-200. 1p. o. p.)

Grūtāk interpretējams ir gulošo svītrinu lietojums R. Klota rokrakstā. Tās var būt gan defises, gan domuzīmes, kaut to garuma ziņā konsekventas atškirīibas nav. Par defisi uzskatāma īsa svītriņa, ar ko Klots dažreiz atdala vārdu morfologisiskos elementus, piemēram, ja-nopuhfchahs, ne-ifśakkoht, ne-kahds, kā arī vieno vārdu savienojuma komponentus, kas apzīmē vienu ¡ēdzienu: bafnizas-waldiśchanas, behdu-muhfchâ, debbes-śchkuhnîs, deenasdarbu, Deewa-behrneem, Deewa-darba, Deewa-nammâ, Deewa-wahrdu, grehkubuhśchanu, Deewa-kalpośchana, Kriftus-bruhte, nakts-tumśibas, śaules-śiltumu, textes-wahrdi, telts-weetu, teeśas-deena $\mathrm{u}$. tml.

Savukārt par domuzīmi uzskatāmas tās gulošās svìtriņas, kas nevis atdala teikuma gramatiskās sastāvdaḷas, bet apzīmē oratora pauzi, lai runa būtu izteiksmīgāka. Labs piemērs tam ir raksta sākumā minētais Klota sprediķa fragments, kur domuzīme lietota kā pauzes apzīmētāja:

Mihli tizzibas beedri! Juhs śchodeen śchè śchurp eśśat śaaizinati śchinnî śawâ Deewa-nammâ. - Bet woi tad śchodeen kahda śwehdeena? - Woi tad śchee kahdi śwehtki? - Ne, m. t. b., ta gan naw. Bet śchi deena mums nolikta no bafnizas-waldiśchanas preekśchneekeem, pahrraudfiht ścho draudfi un apluhkoht, woi ta Deewa-kalpośchana pee mums noteek kà waijaga, - woi behrni tohp audfehti eekśch ta Kunga Jefus atfihśchanas un pamahziśchanas, - woi laulati draugi mihleśtibâ un śaderribâ dfihwo, - woi ikweens darbojahs eekśch tahm Deewa leetahm, un woi wiśśa śchi draudfe arri dfennahs, tahda draudfe palikt ikdeenas jo wairak, kurrai nebuhtu nekahds traipeklis, nedf grumba, nedf zitta kahda waine, bet kas buhtu śwehta un befwainiga,- weena ihśtena Kriftus-bruhte. (LVVA 1851: 198. 1p.)

\section{Nobeigums}

Mācītāja R. Klota 1851. gada rokraksts ir raksturīgs 19. gs. vidus teksts. Viņa vizitācijas spredikikis Mālpils draudzei ir emocionāli piesātināts ar romantisma iezīmēm. 
Teksta latviešu ortogrāfija, kā arī fonētika kopumā atbilst citiem 19. gs. vidus rakstiem. Trūkst konsekvences /s/, /š/ šksīrumā no /z/, /ž/, nav apzīmēti /ks/, /g̊g . Bieži pārsvītrojuma nav arī mīksto līdzskaņu /1̣,/, /ņ/ un /ṛ/ rakstībā. Ortogrāfijas jauninājums varētu būt vienkāršais $\langle\mathrm{v}\rangle$, kuru Klots lieto līdztekus tradicionālajam $<\mathrm{w}>$.

Rokraksta valodas morfolog̣ija un sintakse pamatos sakrīt ar sava laika rakstu valodas tradīciju. Spilgtas iezīmes: 1) substantīvu celmu atšķ̌irība; 2) bieži lietoti ar -šana, -ība, -ums atvasināti substantīvi; 3) raksturīgi ar -īgs atvasināti adjektīvi; 4) lietotas seniskas pronomenu formas manim, tevim, sevim; 5) sastopamas dažas dialektālas un arhaiskas verbu formas; 6) dažas savdabības un svārstības locịjumu lietošanā; 7) domuzīme daudzviet ir lietota oratora pauzes nozīmē.

Rakstītāja latviešu valodā atrodamas arī vairākas laikmetam raksturīgas vācu valodas pēdas: 1) artikulu nozīmē lietotie vārdi tas, viens; 2) prepozīcijas caur, iekš, no, priekš, uz lietotas arī vācu valodai raksturīgās nozīmēs; 3) nesaskaņotās apzīmētāja grupas bieži novietotas aiz apzīmējamā vārda.

\section{Avoti}

LVVA $1851=$

Latvijas Valsts vēstures arhīvs. Vidzemes evaņgēeliski luteriskā konsistorija. Konsistoriālā iecirkṇa vizitāciju protokoli. 233. fonds, 3. apraksts, 3010. lieta, 198.-202. lp.

\section{Literatūra}

BV $1871=$

Baerent, Paul. 1977.

Bergmane, Anna. Blinkena, Aina. 1986.

Blese, Ernests. 1929.

$\mathrm{DBL}=$

DI $1842=$

DI $1857=$

$\mathrm{EH}=$

Endzelīns, Jānis. 1951.

Endzelīns, Jānis,

Kārlis Mīlenbahs. 1907.
Dažādas ziṇas (no iekšzemes). Baltijas Vēstnesis, Nr. 52 (29.12.1871.).

Die evangelischen Prediger Livlands bis 1918. Köln, Wien: Böhlau.

Latviešu rakstības attīstība. Latviešu literārās valodas vēstures pētījumi. Rīga: Zinātne.

Latviešu personu vārdu un uzvārdu studijas. I. Vecākie personu vārdi un uzvārdi (XIII-XVI g. s.). Ar īsu satura un svarīgāko slēdzienu kopsavilkumu vācu valodā. Izdots ar kultūras fonda pabalstu. Rīga: A. Gulbis.

Deutschbaltisches Biographisches Lexikon 1710-1960.

Personalnotizen. Das Inland, Nr. 10 (10.03.1842.).

Korrespondenz. Das Inland, Nr. 30 (29.07.1857.).

J. Endzelīns un E. Hauzenberga. Papildinājumi un labojumi K. Mīlenbaha Latviešu valodas vārdnīcai. I-II. Rīga, 1934-1946. Latviešu valodas gramatika. Rīga: Latvijas Valsts izdevniecība. Latweeśchu gramatika. Rigâ: K. J. Sichmaņa apgahdibâ. 
KV $1911=$

KV $1921=$

Klekere-Krekele, Ināra. 2011.

\section{LA $1864=$}

LFV II =

$\mathrm{ME}=$

MV $1863=$

MV $1872=$

Paegle, Dzintra. 2019.

Pauloviča, Ieva. 2011.

Plāķis, Juris. 1936.

Pokrotniece, Kornēlija. 1991.

\section{RK $1870=$ \\ RK $1876=$}

RZ $1876=$

Rinkužs, Kārlis. 1938.

Rosenberger, [Otto]. 1830.

Rudzīte, Marta. 1964.

Seniespiedumi. 1999.

Švābe, Arveds. 1958.

TLD $1842=$

Vanags, Pēteris. 2013.
Konversacijas vārdnīca. Trešais sējums. Rīga: R.L.B. Derīgu Grāmatu nodaḷa.

Konversacijas vārdnīca. Ceturtais sējums. Rīga: R.L.B. Derīgu Grāmatu nodaḷa.

Latviešu dzejas publikācijas un vienotas literārās telpas veidošanās 1789-1855. Promocijas darbs bibliotēku zinātnes apakšnozarē. Darba zin. vad. Dr. philol. Viesturs Zanders. Rīga.

Dīnsberg. Vidzemes skolmeisteru=skolas un skolas kunga Cimzes goda diena. Latviešu Avizzes, Nr. 34 (20.08.1864.).

Laua, Alise, Aija Ezeriņa, Silvija Veinberga. Latviešu frazeologiijas vārdnīca divos sējumos. II. N-Ž. Rīga: Avots, 1996.

K. Mīlenbaha Latviešu valodas vārdnīca. Redig̣ejejis, papildinājis, turpinājis J. Endzelīns. I-IV. Rīga: Kultūras fonds,1923-1932. Ebgr. Vidzemes skolmeisteru saiešana Turaidē 1863. gadā. Mājas Viesis, Nr. 24 (08.07.1863.).

J. Kakting. „Dziesmu rota jaunekḷiem un vīriem“ I, II. Mājas Viesis, Nr. 12 (18.03.1872.).

Ērgḷu un Ogresmuižas luterāṇu mācītāja Fridriha Vilhelma Veiriha 1850. gada sprediķis latviešu valodā. Baltu filoloǵija XXVIII (2), 123-142.

Mālpils Dievmātes Patvēruma Pareizticīgo draudze 19. gs. Mālpils Vēstis. Nr. 1 (117), 2 (118).

Latvijas vietu vārdi un latviešu pavārdi. I daḷa. Kurzemes vārdi profesora J. Plāķa sakrāti un sakārtoti. LŪR Filolog̣ijas un filozofijas fakultāte. Sērija IV sējums. 1. Rīga: LU.

J. Lange un „Latviešu Ārste“. P. E. Vilde. Latviešu Ārste jeb ìsa mācība no tām Vājībām un no šās Zemes Zālēm, ar kuṛām Cilvēkus un Lopus var ārstēt un izzālotot. Jākoba Langes 1768. gada tulkojuma teksts. Rīga: Zvaigzne, 199-218.

Veränderungen. Rigasches Kirchenblatt. Nr. 52 (28.08.1870.).

Aus den Kirchenbüchern. Rigasches Kirchenblatt. Nr. 13 (26.03.1876.).

Inland. Riga 23. Oktober. Rigasche Zeitung, Nr. 247 (23.10.1876.). Jānis Cimze. Rīga: Valters un Rapa.

Formenlehre der lettischen Sprache. Conspect für seine Zuhörer. Mitau: Joh. Friedr. Steffenhagen und Sohn.

Latviešu dialektolog̣ija. Rīga: Latvijas Valsts izdevniecība.

Seniespiedumi latviešu valodā. 1525-1855. Kopkatalogs. Izstrādājis autoru kolektīvs Silvijas Šiško vadībā. Zinātniskais redaktors Aleksejs Apīnis. Rīga: Latvijas Nacionālā bibliotēka.

Latvijas vēsture 1800-1914. Stokholma: Daugava.

Jaunas ziņas. Iz Rīgas. Tas Latviešu Draugs, Nr. 10 (05.03.1842.).

Latviešu literārās valodas attīstība. Latvieši un Latvija. I sējums. Latvieši. Atbildīgie redaktori: Ilga Jansone, Andrejs Vasks. Rīga: Latvijas Zinātṇu akadēmija, 177-203. 
Vanags, Pēteris. 2015.

Vičs, Andrejs. 1928.

Zelče, Vita. 2009.

Zemzare, Daina. 2011 [1961].

Dzintra Paegle

Baltu valodniecības katedra

Humanitāro zinātñu fakultāte

Latvijas Universitāte

Visvalža iela 4a, Rīga, Latvija

dzintrap@latnet.lv

Pèteris Vanags

Baltu valodniecības katedra

Humanitāro zinātnu fakultāte

Latvijas Universitäte

Visvalža iela 4a, Rīga, Latvija

pvanags@latnet.lv
Valoda „Stāstos”. F. B. Blaufūss. Vidzemes Stāsti. Stāsti no tās vecas un jaunas būšanas to Vidzemes laužu, uzrakstīti 1753. Rīga: Vēstures izpētes un popularizēšanas biedrība.

Latviešu skolu vēsture. Trešā grāmata. Vidzeme no 1800.1855. gadam. Rīga: R.L.B. Derīgu grāmatu nodạ̣a.

Latviešu avīžniecība. Laikraksti savā laikmetā un sabiedrībā.1822-1865. Rīga: Zinātne.

Kāds XVIII gs. krievu-vācu-latviešu-igauṇu salīdzināmās vārdnīcas manuskripts. Leksikologijas un leksikogrāfijas jautājumi. LPSR ZA Valodas un literatūras institūta Raksti, 13. laid. Rīga: ZA izdevniecība, 301-319. [= Daina Zemzare. Darbu izlase. Sast. un zin. red. Ilga Jansone. Rīga: LU Latviešu valodas institūts. 346-363.]

\section{SUMMARY}

\section{An 1851 Sermon in Latvian by Otto Robert von Klot (1808-1876), Lutheran Pastor at Mālpils}

\section{Dzintra PAEGLE, Pēteris VANAGS}

The article analyses the sermon by the Lutheran pastor Otto Robert von Klot (LVVA 1851), which was read during a church visitation to the Latvian congregation on October 11, 1851 at Mālpils Evangelical Lutheran Church in the Riga District. The article discusses and clarifies the pastor's biography, considers the content and expression of the handwritten sermon, the peculiarities of the use of orthography, morphology of nouns, adjectives and verbs, as well as some peculiarities of syntax and punctuation.

The manuscript of Pastor Klot is a typical mid-19th century text. His sermon is emotionally saturated with features of romanticism.

The Latvian orthography of the manuscript, as well as the phonetics in general correspond to other mid-19th century texts. There is a lack of consistency in the separation of consonants $/ \mathrm{s} /, / \check{\mathrm{s}} /$ from $/ \mathrm{z} /, / \check{\mathrm{z}} /$. Palatalization of the consonants $/ \mathrm{k} /, / \mathrm{g} /$ is never marked. 
Often there are no diacritics to denote the palatal consonants $/ 1 /, / \mathrm{n} /$ and $/ \mathrm{r} /$. An orthographic innovation could be the simple $<\mathrm{v}>$ that Klot uses alongside the traditional $<\mathrm{w}>$.

The morphology and syntax of the manuscript basically coincides with the written language tradition of its time. Some specific features: 1) variation of noun stems; 2) often-used derived nouns with suffixes -šana, -ība, -ums; 3) derived adjectives with suffix -īgs; 4) archaic pronoun forms manim, tevim, sevim; 5) several dialectical and archaic forms of verbs; 6) some peculiarities and variations of case forms; 7) a dash is used in many instances in the sense of a speaker's pause.

The Latvian language of the manuscript has several traces of the influence of the German language typical of the time: 1) the pronouns tas, $t \bar{a}$ and numerals viens, viena are often used in the meaning of the definite or indefinite article; 2) the prepositions caur, iekš, no, priekš, $u z$ are often used in the meanings typical to the German language; 3) attributive groups in the genitive are often placed after the head word. 